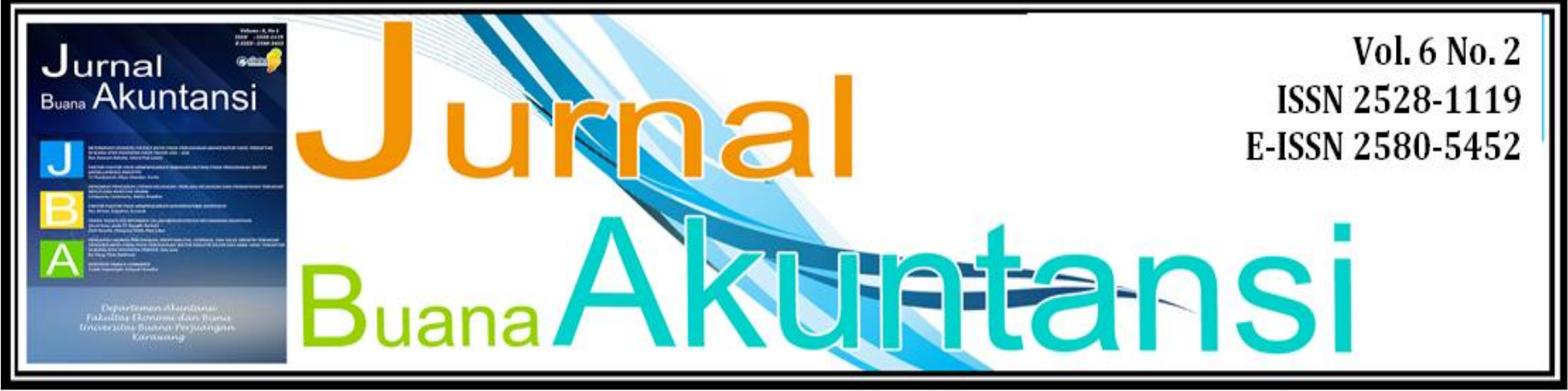

\title{
Analisis Faktor Faktor Yang Mempengaruhi Penanaman Modal Asing di Indonesia
}

\author{
Herry Wira Wibawa ${ }^{1 *}$, Dewi Nari Ratih Permada ${ }^{2}$ \\ ${ }^{1}$ Sekolah Tinggi Ilmu Ekonomi Swadaya, Jakarta Timur - Indonesia \\ ${ }^{2}$ Fakultas Ekonomi, Universitas Pamulang, Tangerang Selatan - Indonesia \\ ${ }^{1}$ hwwibawa@gmail.com
}

\begin{abstract}
Abstrak (ringkasan) Tujuan penelitian ini adalah untuk mengkaji dan menganalisis pengaruh: Tingkat suku bunga international, Kurs Rupiah terhadap Dollar, Tingkat suku bunga domestik, Inflasi, Produk domestik bruto secara simultan dan pasial terhadap Penanaman modal asing . Penelitian ini menggunakan hubungan sebab akibat. Jenis data yang digunakan adalah data sekunder dalam bentuk time series, model dan teknik analisis menggunakan regresi linier berganda dan sederhana dengan pendekatan residual. Hasil penelitian variabel Tingkat suku bunga international, Kurs Rupiah terhadap Dollar, Tingkat suku bunga domestik, Inflasi dan Produk domestik bruto terdapat pengaruh signifikan terhadap Penanaman modal asing. Hal ini menunjukkan apabila pertumbuhan ekonomi Indonesia positif maka akan mengundang daya tarik investor untuk berinvestasi, produk domestik bruto sebagai faktor yang mempengaruhi penanaman modal asing di Indonesia akan terus meningkat menggambarkan pertumbuhan ekonomi yang positif.
\end{abstract}

Kata Kunci: Moneter, PDB, Penanaman Modal Asing

\section{Pendahuluan}

Penanaman modal asing (Foreign Direct Investment FDI) memainkan peran penting dalam pembangunan ekonomi negara-negara berkembang. Setiap negara, termasuk Indonesia, secara agresif mendorong arus masuk penanaman modal asing untuk mempercepat pertumbuhan ekonomi, karena efek dari penanaman modal asing relatif sebagai pertumbuhan ekonomi negara-negara berkembang.

United Nations Conference Trade and Development (UNCTAD) telah merilis laporan terkait investasi dunia yang dirangkum dalam World Investment Report 2015 tentang penanaman modal asing di tiap-tiap negara berkembang di dunia tahun 2014, bahwa Asia Timur dan Asia Tenggara merupakan salah satu wilayah tujuan investasi asing terbesar di dunia. Dengan penanaman modal asing sebesar US\$ 381 miliar dan tingkat pertumbuhan sebesar 9,6 persen, 


\section{Buana Akuntansi}

Herry dan Dewi

Vol. 6 No. 2

ISSN 2528-1119

E-ISSN 2580-5452

kawasan Asia Timur dan Asia Tenggara memiliki porsi 31 persen dari seluruh penanaman modal asing yang terdapat di seluruh dunia.

Peningkatan penanaman modal asing dianggap penting dalam menjamin kelangsungan pembangunaan dibandingkan dengan aliran bantuan atau modal portofolio, sebab terjadinya penanaman modal asing disuatu negara akan diikuti dengan transfer of technology, know-how, management skill, resiko usaha relatif kecil dan lebih profitable. Sebagai bentuk aliran modal yang bersifat jangka panjang dan relatif tidak rentan terhadap gejolak perekonomian, FDI diharapkan untuk membantu mendorong pertumbuhan investasi yang sustainable di Indonesia.

Penelitian ini merumuskan masalah sebagai berikut: (1) Bagaimana pengaruh Tingkat suku bunga international, Kurs Rupiah terhadap US Dollar, Tingkat suku bunga domestik, Inflasi, Produk domestik bruto terhadap Penanaman Modal Asing secara simultan? dan (2) Berapa besar variabel independen Tingkat suku bunga international, Kurs Rupiah terhadap US Dollar, Tingkat suku bunga domestik, Inflasi, Produk domestik bruto secara parsial mampu menjelaskan variabel dependen Penanaman Modal Asing?

Tujuan dalam penelitian ini yaitu: (1) Mengkaji dan menganalisis pengaruh Tingkat suku bunga international, Kurs Rupiah terhadap US Dollar, Tingkat suku bunga domestik, Inflasi, Produk domestik bruto terhadap Penanaman Modal Asing secara simultan; dan (2) Menganalisa besarnya variabel independen Tingkat suku bunga international, Kurs Rupiah terhadap US Dollar, Tingkat suku bunga domestik, Inflasi, Produk domestik bruto, secara parsial mampu menjelaskan variabel dependen Penanaman Modal Asing.

\section{Tinjauan Pustaka}

2.1. Hasil Penelitian Terdahulu

Tabel 1. Hasil Penelitian yang Relevan

\begin{tabular}{|c|c|c|c|}
\hline No & Peneliti dan Judul & Variabel & Temuan Penelitian \\
\hline 1 & $\begin{array}{l}\text { Yilmaz Bayar (2014) } \\
\text { Saving, Foreign Direct Investment } \\
\text { Inflows and Economic Growth in } \\
\text { Emerging Asian Economies }\end{array}$ & $\begin{array}{l}\text { Pertumbuhan } \\
\text { ekonomi, } \\
\text { tabungan } \\
\text { domestik } \\
\text { bruto, } \\
\text { FDI }\end{array}$ & $\begin{array}{l}\text { Tabungan domestik bruto, Investasi } \\
\text { domestik bruto dan arus masuk investasi } \\
\text { asing memiliki efek positif pada } \\
\text { pertumbuhan ekonomi dalam jangka } \\
\text { panjang. }\end{array}$ \\
\hline 2 & $\begin{array}{l}\text { Rupal Chowdhary and Vivek } \\
\text { Kushwaha (2013) } \\
\text { Domestic investment, Foreign Direct } \\
\text { Investment and Economic Growth in } \\
\text { India since Economic }\end{array}$ & $\begin{array}{l}\text { Investasi } \\
\text { dalam negeri, } \\
\text { FDI dan } \\
\text { Pertumbuhan } \\
\text { Ekonomi }\end{array}$ & $\begin{array}{l}\text { FDI dan investasi dalam negeri tidak } \\
\text { meningkat. FDI dan pertumbuhan } \\
\text { ekonomi tidak memiliki hubungan } \\
\text { sebab-akibat dan FDI tidak mempercepat } \\
\text { pertumbuhan ekonomi }\end{array}$ \\
\hline 3 & $\begin{array}{l}\text { Nikolas Hourvouliades and } \\
\text { Ljupco Davcev (2014) } \\
\text { The Influence of Foreign Invesments } \\
\text { on Employment and Economic } \\
\text { Growth in Fyrom. }\end{array}$ & $\begin{array}{l}\text { FDI, } \\
\text { pertumbuhan } \\
\text { ekonomi,peng } \\
\text { angguran }\end{array}$ & $\begin{array}{l}\text { FDI pada pertumbuhan ekonomi dan } \\
\text { pengangguran, masa transisi, yang } \\
\text { memiliki kekhasan tersendiri dalam arus } \\
\text { masuk FDI sebagai bentuk pertumbuhan } \\
\text { ekonomi yang cepat. }\end{array}$ \\
\hline 4 & $\begin{array}{l}\text { Najia Saqib, Maryam Masnoon } \\
\text { and Nabeel Rafique (2013) } \\
\text { Impact of Foreign Direct Investment }\end{array}$ & $\begin{array}{l}\text { FDI, Utang, } \\
\text { Perdagangan, } \\
\text { Inflasi dan }\end{array}$ & $\begin{array}{l}\text { Kinerja ekonomi Pakistan negatif oleh } \\
\text { FDI sedangkan Investasi dalam negeri } \\
\text { diuntungkan ekonominya. Selain itu }\end{array}$ \\
\hline
\end{tabular}




\section{Buana Akuntansi}

\begin{tabular}{|c|l|l|l|}
\hline & on Economic Growth of Pakistan & $\begin{array}{l}\text { Investasi } \\
\text { dalam negeri }\end{array}$ & $\begin{array}{l}\text { utangnegara,perdagangan dan inflasi } \\
\text { negative terhadap PDB. Kebijakan } \\
\text { ekonomi membatasi FDI di Pakistan dan } \\
\text { mendorong tabungan domestik dan } \\
\text { investasi dalam negeri harus dirumuskan } \\
\text { dan dilaksanakan. Keuntungan FDI } \\
\text { kembali ke negara investor. }\end{array}$ \\
\hline 5 & $\begin{array}{l}\text { Guluzar Kurt Gumus (2013) } \\
\text { The Relationship Between Foreign } \\
\text { Portfolio Invesment and } \\
\text { Macroeconomic }\end{array}$ & $\begin{array}{l}\text { Portofolio } \\
\text { FDI, Makro } \\
\text { ekonomi }\end{array}$ & $\begin{array}{l}\text { Portofolio FDI mempengaruhi Bursa Efek } \\
\text { Istanbul, Indeks harga dan nilai tukar. } \\
\text { Hanya indeks produksi industri } \\
\text { mempengaruhi portofolio FDI. }\end{array}$ \\
\hline 6 & $\begin{array}{l}\text { Zenasni Soumia and Benhabib } \\
\text { Abderrezzak (2013) } \\
\text { The Determinants of Foreign Direct } \\
\text { Investment and Their Impact on } \\
\text { Growth }\end{array}$ & $\begin{array}{l}\text { FDI dan } \\
\text { Pertumbuhan } \\
\text { Sektor } \\
\text { ekonomi }\end{array}$ & $\begin{array}{l}\text { FDI dianggap sebagai faktor kunci } \\
\text { menuju kemajuan di sektor ekonomi. } \\
\text { Jenis pendanaan eksternal menunjukkan } \\
\text { tren meningkat dari waktu ke waktu. }\end{array}$ \\
\hline
\end{tabular}

\subsection{Posisi Penelitian}

Berdasarkan penelitian terdahulu yang relevan, maka posisi penelitian ini adalah Tingkat suku bunga international, Kurs Rupiah terhadap Dollar, Tingkat suku bunga domestik, Inflasi dan Produk domestik bruto terhadap Penanaman modal asing yang merupakan pembaruan dari penelitian yang dilakukan oleh peneliti lain Indikator pada penelitian ini merekontruksi teori yang ada dari penelitian-penelitian terdahulu yaitu mengembangkan, memperkaya pendekatan teori baru yang adaptif dengan konteks Indonesia.

2.2.1. Pengaruh Tingkat suku bunga international positif terhadap Penanaman modal asing (FDI)

Pengaruh tingkat suku bunga international terhadap Penanaman modal asing juga dipengaruhi oleh keadaan ekonomi internasional yang tercermin dari suku bunga internasional, disamping itu juga investor memperhatikan keadaan ekonomi negara yang dituju untuk melakukan investasinya dalam jangka panjang. Dari hasil ini dapat disimpulkan bahwa investor-investor asing tidak saja dominan memperhatikan tingkat suku bunga international LIBOR sebagai suku bunga acuan dalam melakukan kegiatan investasinya.

Tingkat suku bunga international LIBOR signifikan mempengaruhi realisasi penanaman modal asing, secara arah tingkat suku bunga international mempunyai hubungan positif. Sehingga hal ini perlu diperhatikan untuk kedepannya, jangan sampai tingginya tingkat suku bunga international menjadi salah satu penghambat masuknya investor penanaman modal asing ke Indonesia.

2.2.2. Pengaruh Kurs Rupiah terhadap Dollar positif terhadap Penanaman modal asing (FDI).

Nilai kurs terkait dengan konsep daya saing (competitivenes). Hal ini akan mendorong mengalirnya penanaman modal asing ke negara yang mengalami depresiasi nilai tukar, akan tapi yang harus digaris bawahi bahwa tidak kemudian mengambil kebijakan untuk menurunkan nilai tukar demi menarik investasi kedalam sebuah negara akan tetapi ketika nilai tukar terdepresiasi akan menjadi salah satu bahan pertimbangan bagi investor- investor, khususnya investor-investor asing untuk melakukan investasinya ke negara tersebut. Penelitian ini diperkuat oleh penelitian yang dilakukan oleh Eliza (2013), serta Frederica dan Juwita (2012) 


\section{Buana Akuntansi}

2.2.3. Pengaruh Tingkat suku bunga domestik negatif terhadap Penanaman modal asing (FDI)

Terdapatnya pengaruh yang signifikan dan negatif antara tingkat suku bunga domestik terhadap penanaman modal asing mengindikasikan bahwa penanaman modal asing di Indonesia ditentukan oleh tingkat suku bunga domestik. Terjadinya peningkatan tingkat suku bunga domestik maka penanaman modal asing akan mengalami penurunan.

Begitu sebaliknya, apabila tingkat suku bunga domestik mengalami penurunan maka penanaman modal asing akan mengalami peningkatan karena biaya dari investasi mengalami penurunan. Hal ini sejalan dengan teori Case dan Fair (2007) menyatakan bahwa ada hubungan terbalik antara investasi yang direncanakan dengan tingkat bunga.

2.2.4. Pengaruh Inflasi positif terhadap Penanaman Modal Asing (FDI).

Inflasi dapat mempengaruhi stabilitas perekonomian di suatu negara karena dapat menurunkan produksi. Menurunnya produksi tidak akan diimbangi dengan permintaan barang yang menurun karena tingkat inflasi yang tinggi dalam suatu negara (Sadono Sukirno, 2012;h381). Inflasi memberikan dampak positif terhadap kegiatan investasi berupa biaya investasi yang tinggi. Biaya investasi akan lebih murah jika tingkat inflasi suatu negara rendah dan akan meningkatkan penanaman di Indonesia.

2.2.5. Pengaruh Produk domestik bruto positif terhadap Penanaman modal asing (FDI).

Konsep produk domestik bruto adalah salah satu konsep perhitungan akan pendapatan nasional yang paling penting dibandingkan dengan konsep perhitungan pendapatan naional lainnya. Produk domestik bruto dapat diartikan sebagai nilai barang-barang dan jasa-jasa yang diproduksian di dalam negara dalam satu tahun tertentu (Sadono Sukirno, 2004). Ada 3 pendekatan dalam menghitung produk domestik bruto suatu negara, yaitu dengan pendekatan pendapatan, pendekatan pengeluaran dan pendekatan produksi

\subsection{Kerangka Pemikiran}

Berdasarkan penelitian terdahulu dan Hubungan antar variabel pada kerangka pemikiran dalam penelitian ini bermula dari pendekatan ekonomi pembangunan yang merupakan bagian dari Ekonomi Makro yang berpengaruh terhadap penanaman modal asing.

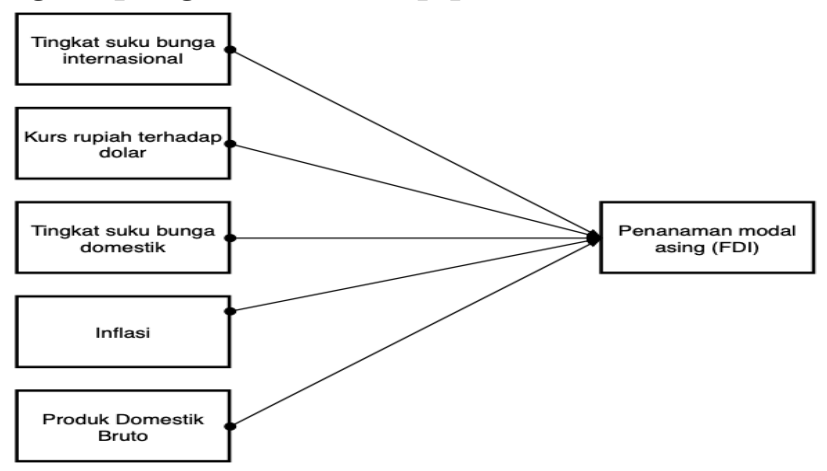

Gambar 1. Kerangka Pemikiran 


\section{Buana Akuntansi}

\section{Metodologi Penelitian}

\subsection{Populasi dan Sampel}

Populasi penelitian meliputi: Tingkat suku bunga international $X_{1}$, Kurs Rupiah terhadap Dollar $X_{2}$, Tingkat suku bunga domestik $X_{3}$, Inflasi $X_{4}$ Produk Domestik Bruto $X_{5}$, Penanaman modal asing (FDI) $Y$ di Indonesia. Teknik sampling dengan cara mengambil seluruh data empiris di Indonesia, selama rentang waktu 35 (tiga puluh lima) tahun, mulai tahun 1985 sampai dengan tahun 2019 dengan observasi $(n)=35$.

\subsection{Metode Penelitian}

Penelitian ini merupakan hubungan sebab akibat / hubungan kausal (Causal Effect), dimana penelitian yang dilakukan untuk memperoleh fakta dari fenomena yang ada dan mencari keterangan secara faktual tentang pengaruh Tingkat suku bunga international $X_{1}$, Kurs Rupiah terhadap Dollar $X_{2}$, Tingkat suku bunga domestik $X_{3}$, Inflasi $X_{4}$ Produk Domestik Bruto $X_{5}$ terhadap Penanaman modal asing (FDI) $Y$ di Indonesia. Jenis data yang digunakan adalah data sekunder, model dan teknik analisis menggunakan regresi linier berganda dengan pendekatan residual. Untuk ketepatan perhitungan sekali gus mengurangi human error, digunakan program Eviews dengan penetapan tingkat signifikansi pada confidence level 95 persen atau a (alpha) 0,05.

Tabel 2. Rangkuman Metode Penelitian

\begin{tabular}{|c|l|l|}
\hline No. & Desain & Keterangan \\
\hline 1 & Tujuan Penelitian & $\begin{array}{l}\text { Pengujian Hipotesis } \\
\text { Vape Hubungan Antar } \\
\text { (Causal Effect) }\end{array}$ \\
\hline 3 & Lingkungan Penelitian & $\begin{array}{l}\text { Kebijakan Moneter } \\
\text { Produk Domestik Bruto } \\
\text { Penanaman Modal Asing }\end{array}$ \\
\hline 4 & Alat Analisis & Regresi Linier Berganda \\
\hline 5 & Pengukuran Konstruk & Persen dan Rupiah \\
\hline 6 & $\begin{array}{l}\text { Metode Pengumpulan } \\
\text { Data }\end{array}$ & Data sekunder \\
\hline 7 & Dimensi Waktu & 35 Tahun \\
\hline
\end{tabular}

\section{Analisis dan Pembahasan}

\subsection{Hasil Penelitian}

Bab hasil dan pembahasan ini terdiri dari dua bagian yaitu: Bagian pertama, menguraikan data data tentang penelitian secara deskriptif meliputi: Tingkat suku bunga international $X_{1}$, Kurs Rupiah terhadap Dollar $X_{2}$, Tingkat suku bunga domestik $X_{3}$, Inflasi $X_{4}$ Produk Domestik Bruto $X_{5}$ sebagai variabel-variabel bebas atau independent (kelompok variabel $X$ ). Kemudian dilanjutkan dengan uraian Penanaman modal asing (FDI) $(Y)$ sebagai variabel terikat.

Bagian kedua memuat tentang pengolahan data dan analisis data, yang terdiri dari: Uji kelayakan model untuk memilih antara model raw data dengan model ln data yang akan di jadikan materi pembahasan, uji asumsi klasik seperti multi kolinearitas, heteroskedastisitas, dan 


\section{Buana Akuntansi}

auto korelasi. Kemudian dilanjutkan dengan interpretasi hasil olah data dan uraian implikasi temuan penelitian melalui penggunaan standart operational procedure (SOP) sebagai berikut:

1. Menyiapkan data set variabel-variabel dalam bentuk raw data maupun ln data.

2. Menyiapkan print out olah data yang dihasilkan melalui pengoperasian software Eviews.

3. Merumuskan fungsi penelitian.

4. Merumuskan fungsi matematis penelitian.

5. Merumuskan fungsi operasional penelitian.

6. Menguraikan interprestasi hasil penelitian dan implikasi hasil penelitian.

Pada bagia kedua, pembahasan juga dilengkapi dengan tentang analisis model, uji stasioner data, uji kointegrasi dan uji kesalahan model (ECM).

\subsubsection{Uji Kausalitas Granger}

Pengujian pertama yang dilakukan adalah pengujian perhubungan kausalitas antar variabel dalam model pengujian Granger-causality. Hasil pengujian ini akan menunjukkan ada tidaknya hubungan kausalitas antara variabel dan bagaimana arah hubungannya. Analisa dalam pengujian kausalitas granger akan dibatasi sesuai dalam tujuan penelitian pada bab pendahuluan, yakni pengujian hubungan Tingkat suku bunga international $X_{1}$, Kurs Rupiah terhadap Dollar $X_{2}$, Tingkat suku bunga domestik $X_{3}$, Inflasi $X_{4}$ Produk Domestik Bruto $X_{5}$ terhadap Penanaman modal asing (FDI) $Y$ di Indonesia

1. Kausalitas Tingkat suku bunga international dan penanaman modal asing

Tabel 3. Uji Granger tingkat suku bunga international dan penanaman modal asing

Pairwise Granger Causality Tests

Date: 02/14/21 Time: 21:12

Sample: 19852019

Lags: 2

\begin{tabular}{lcrc}
\hline \hline Null Hypothesis: & Obs & F-Statistic & Prob. \\
\hline \hline X1_LIBOR does not Granger Cause Y_FDI & 33 & 3.66368 & 0.0386 \\
Y_FDI does not Granger Cause X1_LIBOR & & 1.08589 & 0.3514 \\
\hline \hline Sumber data olahan & & &
\end{tabular}

Dari tabel 3 hipotesis nol untuk LIBOR mempengaruhi FDI, dapat dilihat bahwa probabilitas $(0.0386)<a(0,05)$. Hal ini berarti bahwa $H_{0}$ ditolak, yang berarti bahwa Libor mempengaruhi FDI. Atau dengan kata lain, dapat disimpulkan bahwa tingkat suku bunga internasional mempengaruhi penanaman modal asing, untuk hasil kedua, dimana hipotesis nol untuk FDI mempengaruhi LIBOR, dapat dilihat bahwa probabilitas $(0.3514)>\alpha(0,05)$. Hal ini berarti bahwa $H_{0}$ diterima, yang berarti bahwa FDI tidak mempengaruhi Libor, dapat disimpulkan bahwa penanaman modal asing tidak mempengaruhi tingkat suku bunga internasional.

2. Kausalitas Kurs Rupiah terhadap Dollar dan penanaman modal asing

Tabel 4. Uji Granger Kurs rupiah terhadap dolar dan penanaman modal asing Pairwise Granger Causality Tests

Date: 02/14/21 Time: $21: 14$

Sample: 19852019

Lags: 2

\begin{tabular}{lccc}
\hline Null Hypothesis: & Obs & F-Statistic & Prob. \\
\hline \hline X2_KURS does not Granger Cause Y_FDI & 33 & 0.54042 & 0.5885 \\
Y_FDI does not Granger Cause X2_KURS & & 1.93191 & 0.1637 \\
\hline \hline Sumber data olahan & & &
\end{tabular}




\section{Buana Akuntansi}

Dari tabel 4 hipotesis nol untuk Kurs mempengaruhi FDI, dapat dilihat bahwa probabilitas $(0,5885)>a(0,05)$. Hal ini berarti bahwa $H_{0}$ diterima, yang berarti bahwa Kurs tidak mempengaruhi FDI. Atau dengan kata lain, dapat disimpulkan bahwa kurs rupiah terhadap dolar tidak mempengaruhi penanaman modal asing, untuk hasil kedua, dimana hipotesis nol untuk FDI mempengaruhi Kurs, dapat dilihat bahwa probabilitas $(0,1637)>a(0,05)$. Hal ini berarti bahwa $H_{0}$ diterima, yang berarti bahwa FDI tidak mempengaruhi Kurs, dapat disimpulkan bahwa penanaman modal asing tidak mempengaruhi kurs rupiah terhadap dolar.

3. Kausalitas Tingkat suku bunga domestik dan penanaman modal asing.

Tabel 5. Uji Granger Tingkat suku bunga domestik dan penanaman modal asing Pairwise Granger Causality Tests

Date: 02/14/21 Time: 21:16

Sample: 19852019

Lags: 2

\begin{tabular}{lccc}
\hline \hline Null Hypothesis: & Obs & F-Statistic & Prob. \\
\hline \hline X3_JIBOR does not Granger Cause Y_FDI & 33 & 6.52132 & 0.0047 \\
Y_FDI does not Granger Cause X3_JIBOR & & 0.70241 & 0.5039 \\
\hline \hline Sumber data olahan & & &
\end{tabular}

Dari table 5 hipotesis nol untuk JIBOR mempengaruhi FDI, dapat dilihat bahwa probabilitas $(0,0047)<\alpha(0,05)$. Hal ini berarti bahwa $H_{0}$ ditolak, yang berarti bahwa JIBOR mempengaruhi FDI. Atau dengan kata lain, dapat disimpulkan bahwa tingkat suku bunga domestik mempengaruhi penanaman modal asing, untuk hasil kedua, dimana hipotesis nol untuk FDI mempengaruhi JIBOR, dapat dilihat bahwa probabilitas $(0.5039)>a(0,05)$. Hal ini berarti bahwa $H_{0}$ diterima, yang berarti bahwa FDI tidak mempengaruhi JIBOR, dapat disimpulkan bahwa penanaman modal asing tidak mempengaruhi tingkat suku bunga domestik.

4. Kausalitas Inflasi dan penanaman modal asing

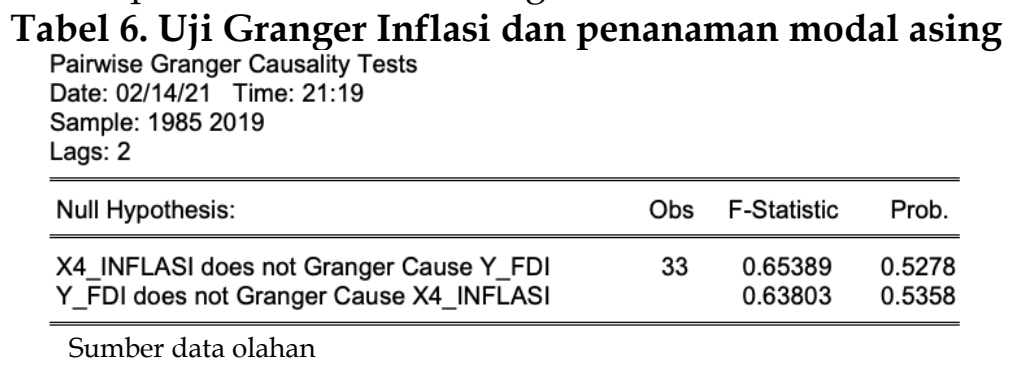

Dari tabel 6 hipotesis nol untuk Inflasi mempengaruhi FDI, dapat dilihat bahwa probabilitas $(0,5278)>$ a $(0,05)$. Hal ini berarti bahwa $H_{0}$ diterima, yang berarti bahwa inflasi tidak mempengaruhi FDI. Atau dengan kata lain, dapat disimpulkan bahwa inflasi mempengaruhi penanaman modal asing, untuk hasil kedua, dimana hipotesis nol untuk FDI mempengaruhi Inflasi, dapat dilihat bahwa probabilitas $(0,5358)>a(0,05)$. Hal ini berarti bahwa $H_{0}$ diterima, yang berarti bahwa FDI tidak mempengaruhi inflasi, dapat disimpulkan bahwa penanaman modal asing tidak mempengaruhi inflasi.

5. Kausalitas Produk Domestik Bruto dan penanaman modal asing

Tabel 7. Uji Granger Produk Domestik Bruto dan penanaman modal asing 


\section{Buana Akuntansi}

Herry dan Dewi

Vol. 6 No. 2

ISSN 2528-1119

E-ISSN 2580-5452

Pairwise Granger Causality Tests
Date: 02/14/21 Time: 21:20
Sample: 19852019
Lags: 2

Dari tabel 7 hipotesis nol untuk PDB mempengaruhi FDI, dapat dilihat bahwa probabilitas $(0,0318)<$ a $(0,01)$. Hal ini berarti bahwa $H_{0}$ ditolak, yang berarti bahwa PDB mempengaruhi FDI. Atau dengan kata lain, dapat disimpulkan bahwa Produk domestik bruto mempengaruhi penanaman modal asing, untuk hasil kedua, dimana hipotesis nol untuk FDI mempengaruhi PDB, dapat dilihat bahwa probabilitas $(0,2295)>$ a $(0,01)$. Hal ini berarti bahwa $H_{0}$ diterima, yang berarti bahwa FDI tidak mempengaruhi PDB, dapat disimpulkan bahwa penanaman modal asing tidak mempengaruhi Produk domestik bruto.

4.1.2. Uji Asumsi Klasik

Uji asumsi klasik yang dipergunakan dalam penelitian ini adalah uji Normalitas, uji multikolinieritas, uji heteroskedastisitas, dan uji Otokorelasi.

1. Uji Normalitas

Uji Normalitas Jarque-Bera gambar 5 dapat dijabarkan bahwa metode pengambilan keputusan untuk uji normalitas dimana model persamaan nilai $X^{2}$ tabel sebesar 49.80185 dengan demikian dapat ditarik kesimpulan bahwa probabilitas gangguan regresi tersebut terdistribusi secara normal karena nilai Jarque Bera sebesar 0,217941 lebih kecil dibanding nilai $X^{2}$ tabel sebesar 49.80185 dan probabilitasnya 0,896757 lebih besar dari alpha $5 \%$.

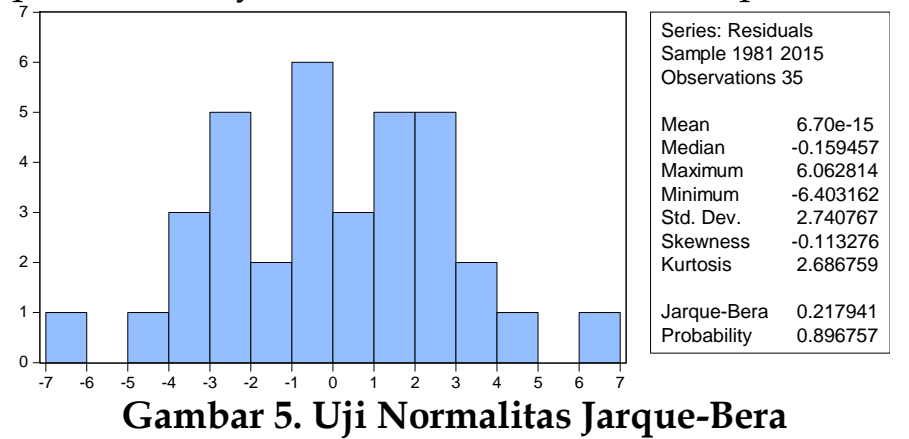

2. Uji Multikolinearitas

Berdasarkan hasil pengujian korelasi pada tabel 3, terlihat bahwa tidak ada variabel yang memiliki nilai korelasi diatas 0,89 (Wing Wahyu Winarno, 2011). Hai ini menyatakan bahwa model regresi ini tidak mengandung masalah multikolinearitas, jadi variabel-variabel tersebut terbebas dari masalah multikolinearitas. 
Multikolinearitas

\begin{tabular}{|c|c|c|c|c|c|}
\hline & X1_LIBOR & X2_KURS & X3_SBI & X4_INFLASI & X5_PDB \\
\hline X1_LIBOR & 1 & $-0,773$ & 0,569 & 0,096 & $-0,856$ \\
\hline X2_KURS & $-0,773$ & 1 & $-0,335$ & 0,111 & 0,815 \\
\hline X3_SBI & 0,569 & $-0,335$ & 1 & 0,747 & $-0,669$ \\
\hline X4_INFLASI & 0,096 & 0,111 & 0,747 & 1 & $-0,188$ \\
\hline X5_PDB & $-0,856$ & 0,815 & $-0,669$ & $-0,188$ & 1 \\
\hline
\end{tabular}

3. Uji Heteroskedastisitas

Berdasarkan hasil perhitungan yang dilakukan Uji White Heteroskedastisitas dengan eviews diperoleh hasil sebagai berikut:

Tabel 4. Uji White Heteroskedastisitas Heteroskedasticity Test: White

\begin{tabular}{|c|c|c|c|c|}
\hline $\begin{array}{l}\text { F-statistic } \\
\text { Obs*R-squared } \\
\text { Scaled explained SS }\end{array}$ & $\begin{array}{l}1.189796 \\
5.957663 \\
3.449522\end{array}$ & \multicolumn{2}{|c|}{$\begin{array}{l}\text { Prob. } F(5,29) \\
\text { Prob. Chi-Square }(5) \\
\text { Prob. Chi-Square }(5)\end{array}$} & $\begin{array}{l}0.3385 \\
0.3104 \\
0.6310\end{array}$ \\
\hline \multicolumn{5}{|c|}{$\begin{array}{l}\text { Test Equation: } \\
\text { Dependent Variable: RESID^2 } \\
\text { Method: Least Squares } \\
\text { Date: } 02 / 13 / 21 \text { Time: } 21: 37 \\
\text { Sample: } 19852019 \\
\text { Included observations: } 35\end{array}$} \\
\hline Variable & Coefficient & Std. Error & t-Statistic & Prob. \\
\hline $\begin{array}{c}\text { C } \\
\text { X1_LIBOR } 2 \\
\text { X2_KURS^2 } \\
\text { X3_JIBOR^2 } \\
\text { X4_INFLASI^2 } \\
\text { X5_PDB^2 }\end{array}$ & $\begin{array}{r}7.103003 \\
-0.006602 \\
0.081392 \\
-0.006850 \\
-1.90 \mathrm{E}-05 \\
-0.118553\end{array}$ & $\begin{array}{l}14.14891 \\
0.113277 \\
0.064979 \\
0.033888 \\
0.007513 \\
0.429684\end{array}$ & $\begin{array}{r}0.502018 \\
-0.058281 \\
1.252578 \\
-0.202124 \\
-0.002527 \\
-0.275907\end{array}$ & $\begin{array}{l}0.6194 \\
0.9539 \\
0.2204 \\
0.8412 \\
0.9980 \\
0.7846\end{array}$ \\
\hline $\begin{array}{l}\text { R-squared } \\
\text { Adjusted R-squared } \\
\text { S.E. of regression } \\
\text { Sum squared resid } \\
\text { Log likelihood } \\
\text { F-statistic } \\
\text { Prob(F-statistic) }\end{array}$ & $\begin{array}{r}0.170219 \\
0.027153 \\
9.484153 \\
2608.526 \\
-125.1087 \\
1.189796 \\
0.338465\end{array}$ & \multicolumn{2}{|c|}{$\begin{array}{l}\text { Mean dependent var } \\
\text { S.D. dependent var } \\
\text { Akaike info criterion } \\
\text { Schwarz criterion } \\
\text { Hannan-Quinn criter. } \\
\text { Durbin-Watson stat }\end{array}$} & $\begin{array}{l}7.297183 \\
9.615599 \\
7.491927 \\
7.758558 \\
7.583968 \\
2.176542\end{array}$ \\
\hline
\end{tabular}

Berdasarkan hasil pengujian dari tabel 4 diatas dimana model persamaan nilai $X^{2}$ tabel sebesar 49,80185 dibandingkan dengan nilai Obs*R-squared sebesar 5,957663. Dengan demikian maka nilai Obs*R-squared uji White lebih kecil dibandingkan nilai $X^{2}$ tabel, sehingga dapat disimpulkan bahwa model regresi persamaan tersebut bebas dari gejala heteroskedastisitas.

4. Uji Autokorelasi

Mendeteksi ada tidaknya otokorelasi dengan menggunakan metode Uji Durbin-Watson Stat.

Tabel 5. Uji Durbin-Watson stat 


\section{Buana Akuntansi}

Herry dan Dewi

Vol. 6 No. 2

ISSN 2528-1119

E-ISSN 2580-5452

\begin{tabular}{|c|c|c|c|c|}
\hline $\begin{array}{l}\text { F-statistic } \\
\text { ObsR-squared }\end{array}$ & $\begin{array}{l}3.631090 \\
7.418568\end{array}$ & \multicolumn{2}{|c|}{$\begin{array}{l}\text { Prob. } F(2,27) \\
\text { Prob. Chi-Square(2) }\end{array}$} & $\begin{array}{l}0.0401 \\
0.0245\end{array}$ \\
\hline \multicolumn{5}{|c|}{$\begin{array}{l}\text { Test Equation: } \\
\text { Dependent Variable: } R E S I D \\
\text { Method: Least Squares } \\
\text { Date: } 02 / 13 / 21 \text { Time: } 21: 39 \\
\text { Sample: } 19852019 \\
\text { Included observations: } 35 \\
\text { Presample missing value lagged residuals set to zero. }\end{array}$} \\
\hline Variable & Coefficient & Std. Error & t-Statistic & Prob. \\
\hline & 10.25162 & 10.72776 & 0.955616 & 0.3477 \\
\hline X1_LIBOR & -0.392800 & 0.390479 & -1.005945 & 0.3234 \\
\hline$\times 2$ KURS & -0.079633 & 0.240450 & -0.331184 & $\begin{array}{l}0.7431 \\
0.4752\end{array}$ \\
\hline $\begin{array}{l}\text { X3-JIBOR } \\
\times 4 \text { INFLASI }\end{array}$ & -0.167502 & 0.231333 & -0.724071 & \\
\hline $\begin{array}{l}\text { X4 INFLASI } \\
\text { X5 PDB }\end{array}$ & $\begin{array}{r}0.075140 \\
-1215490\end{array}$ & $\begin{array}{l}0.083357 \\
1.668033\end{array}$ & $\begin{array}{r}0.901429 \\
-0.728697\end{array}$ & $\begin{array}{l}0.3753 \\
0.4725\end{array}$ \\
\hline RESID(-1) & $\begin{array}{r}-1.215490 \\
0.527662\end{array}$ & $\begin{array}{l}1.668033 \\
0.203467\end{array}$ & 2.593359 & 0.0152 \\
\hline RESID(-2) & 0.073899 & 0.235370 & 0.313971 & 0.7560 \\
\hline R-squared & 0.211959 & \multirow{7}{*}{\multicolumn{2}{|c|}{$\begin{array}{l}\text { Mean dependent var } \\
\text { S.D. dependent var } \\
\text { Akaike info criterion } \\
\text { Schwarz criterion } \\
\text { Hannan-Quinn criter. } \\
\text { Durbin-Watson stat }\end{array}$}} & $6.70 \mathrm{E}-15$ \\
\hline Adjusted R-squared & 0.007652 & & & 2.740767 \\
\hline S.E. of regression & 2.730261 & & & 5.044303 \\
\hline & 201.2668 & & & 5.399811 \\
\hline Log likelihood & -80.27530 & & & 5.167024 \\
\hline $\begin{array}{l}\text { F-statistic } \\
\text { Prob(F-statistic) }\end{array}$ & 1.037454 & & & 2.107006 \\
\hline & 0.428872 & & & \\
\hline
\end{tabular}

Berdasarkan tabel 5 Uji Durbin-Watson stat terlihat nilai Durbin Watson dari pengujian ini adalah sebesar 2,107006. Kemudian hasil ini dibandingkan dengan nilai dU yang diperoleh dari tabel Durbin Watson. Dengan k (jumlah variabel independen) $=5$ dan $n=$ jumlah sampel sebanyak 35 sampel, maka dari tabel Durbin Watson $\mathrm{dL}=1,160$ dan $\mathrm{dU}=1,803$ terletak antara $\mathrm{dU}<\mathrm{d}<(4-\mathrm{dU})$ yaitu $1,803<2,107<2,197$ maka hasil pengujian Durbin-Watson pada persamaan yang ada menunjukkan hasil tidak terdapat korelasi serial, sehingga dapat disimpulkan bahwa model regresi persamaan tersebut bebas dari gejala Otokorelasi.

4.1.3. Analisis Regresi Linier Berganda

Pada analisis regresi linier berganda, melakukan pengolahan data dengan memasukkan data-data untuk selanjutnya dilakukan analisis menggunakan program eviews.

Tabel 6. Regresi Linier Berganda

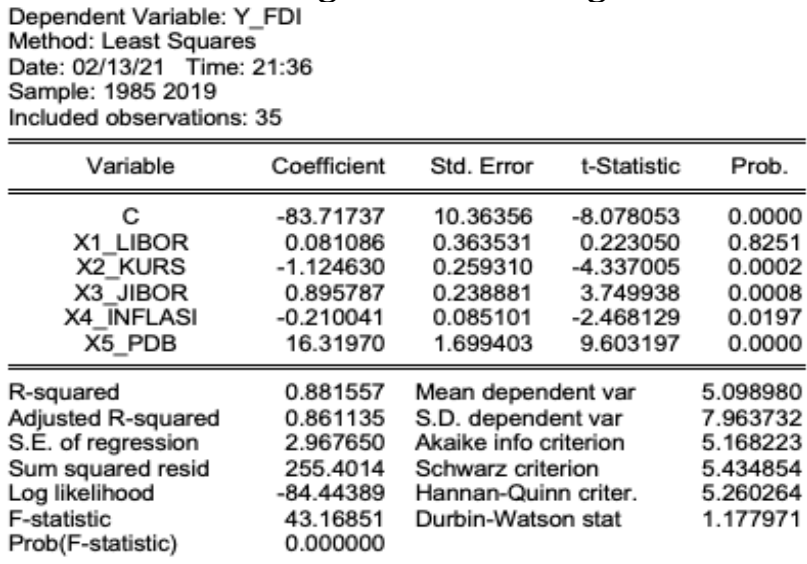

Dengan memperhatikan hasil regresi linear berganda pada table 6 di atas maka diperoleh persamaan regresi sebagai berikut:

$Y_{F D I}=-83,717+0,081 X_{1_{L W O R}}-1,125 X_{2_{\text {KUES }}}+0.896 X_{3_{\text {JWOR }}}-0.21 X_{4_{\text {WNFASI }}}+16,319 X_{5_{F D B}}$

\subsubsection{Pengujian Hipotesis}




\section{Buana Akuntansi}

Herry dan Dewi

Vol. 6 No. 2

ISSN 2528-1119

E-ISSN 2580-5452

\section{Uji Signifikansi Simultan (F-TEST)}

Berdasarkan tabel 6 Regresi Linier Berganda untuk menguji adanya pengaruh secara simultan dengan menggunakan uji $F_{\text {Snecdecor }}$, didapat $F_{\text {hitung }}=43,16851$ dan $\operatorname{Prob}\left(F_{\text {Statistic }}\right)=$ 0,000000 dengan $a=0,05$ sedangkan $F_{\text {table }}$ dengan jumlah $\mathrm{n}=35$ dan jumlah variabel $(\mathrm{k})=5$ derajat kebebasan pada pembilang $\mathrm{k}-1=5-1=4$ dan derajat kebebasan pada penyebut $\mathrm{n}-\mathrm{k}$ $1=35-5-1=29$ dengan menggunakan tingkat signifikansi 5\% (uji dua arah) diperoleh hasil $F_{\text {table }}=2,70$. Dengan demikian $F_{\text {hitung }}$ lebih besar daripada $F_{\text {table }}(43,16851>2,70)$ berarti $H_{0}$ ditolak dan $H_{1}$ diterima yang berarti terdapat pengaruh yang signifikan secara simultan antara Tingkat suku bunga international $\left(X_{1}\right)$, Kurs Rupiah terhadap Dollar $\left(X_{2}\right)$, Tingkat suku bunga domestik $\left(X_{3}\right)$, Inflasi $\left(X_{4}\right)$, Produk Domestik Bruto $\left(X_{5}\right)$ terhadap Penanaman modal asing $(Y)$.

2. Uji Partial (t-TEST)

Uji-t yang dilakukan menggunakan uji satu sisi (one tail test), dengan a $=5 \%$, maka diperoleh t-tabel dengan nilai 2.05553. Dengan demikian maka dapat ditarik kesimpulan:

1) Pengaruh Tingkat suku bunga international LIBOR $\left(X_{1}\right)$ terhadap Penanaman modal asing $(Y)$

Berdasarkan tabel 6, variabel Tingkat suku bunga international LIBOR $\left(X_{1}\right)$ secara statistik menunjukkan hasil yang $P_{\text {Value }}$ lebih besar dari a $(0,8251>0,05)$, sedangkan nilai $t_{\text {hitung }}=0,223050$ dan $t_{\text {table }}$ sebesar 1,69726 $(\operatorname{df}(35-5)=30$, a $=0,05)$ sehingga $t_{\text {hitung }}$ lebih kecil dari $t_{\text {table }}(0,22305<1,69726)$, dapat disimpulkan bahwa hipotesis $H_{0}$ diterima dan $H_{1}$ ditolak, berarti variabel Tingkat suku bunga international LIBOR $\left(X_{1}\right)$ tidak pengaruh signifikan dan negatif terhadap Penanaman modal asing $(Y)$.

2) Pengaruh Kurs Rupiah terhadap Dollar $\left(X_{2}\right)$ terhadap Penanaman modal asing $(Y)$

Berdasarkan tabelm 6, variabel Kurs Rupiah terhadap Dollar $\left(X_{2}\right)$ secara statistik menunjukkan hasil yang $P_{\text {Value }}$ lebih kecil dari a $(0,0002<0,05)$, sedangkan nilai $t_{\text {hitung }}=-4,337005$ dan $t_{\text {table }}$ sebesar 1,69726 $(\mathrm{df}(35-5)=30, a=0,05)$, sehingga $t_{\text {hitung }}$ lebih kecil dari $t_{\text {table }}(-4,337005<1,69726)$, dapat disimpulkan bahwa hipotesis $H_{0}$ ditolak dan $H_{1}$ ditolak, berarti variabel Kurs Rupiah terhadap Dollar $\left(X_{2}\right)$ pengaruh signifikan dan negatif terhadap Penanaman modal asing $(Y)$.

3) Pengaruh Tingkat suku bunga domestik JIBOR $\left(X_{3}\right)$ terhadap Penanaman modal asing $(Y)$

Berdasarkan tabel 6 variabel Tingkat suku bunga domestik JIBOR $\left(X_{3}\right)$ secara statistik menunjukkan hasil yang $P_{\text {Value }}$ lebih kecil dari a $(0,0008<0,05)$, sedangkan nilai $t_{\text {hitung }}$ $=3,749938$ dan $t_{\text {table }}$ sebesar 1,69726 $(\operatorname{df}(35-5)=30, a=0,05)$, sehingga $t_{\text {hitung }}$ lebih besar dari $t_{\text {table }}(3,749938<1,69726)$, dapat disimpulkan bahwa hipotesis $H_{0}$ ditolak dan $H_{1}$ diterima, berarti variabel tingkat suku bunga domestik JIBOR $\left(X_{3}\right)$ pengaruh signifikan dan positif terhadap Penanaman modal asing $(Y)$.

4) Pengaruh Inflasi $\left(X_{4}\right)$ terhadap Penanaman modal asing $(Y)$

Berdasarkan tabel 6, variabel Inflasi $\left(X_{4}\right)$ secara statistik menunjukkan hasil yang $P_{\text {Value }}$ lebih kecil dari a $(0,0197<0,05)$, sedangkan nilai $t_{\text {hitung }}=-2,468129$ dan $t_{\text {table }}$ sebesar 1,69726 $(\operatorname{df}(35-5)=30, a=0,05)$, sehingga $t_{\text {hitung }}$ lebih kecil dari $t_{\text {table }}(-$ $2,468129<1,69726)$, dapat disimpulkan bahwa hipotesis $H_{0}$ ditolak dan $H_{1}$ ditolak, 


\section{Buana Akuntansi}

berarti variabel Inflasi $\left(X_{4}\right)$ pengaruh signifikan dan negatif terhadap Penanaman modal asing $(Y)$

5) Pengaruh Produk domestik bruto $\left(X_{5}\right)$ terhadap Penanaman modal asing $(Y)$

Berdasarkan tabel 6, variabel Produk domestik bruto $\left(X_{5}\right)$ secara statistik menunjukkan hasil yang $P_{\text {Value }}$ lebih kecil dari a $(0,0000<0,05)$, sedangkan nilai $t_{\text {hitung }}=9,603197$ dan $t_{\text {table }}$ sebesar 1,69726 $(\mathrm{df}(35-5)=30, a=0,05)$, sehingga $t_{\text {hitung }}$ lebih besar dari $t_{\text {table }}(9,603197>1,69726)$, maka dapat disimpulkan bahwa hipotesis $H_{0}$ ditolak dan $H_{1}$ diterima, berarti variabel Produk domestik bruto $\left(X_{5}\right)$ pengaruh signifikan dan positif terhadap Penanaman modal asing $(Y)$

3. Uji Goodness of fit (Uji $\left.R^{2}\right)$

Berdasarkan tabel 6, uji goodness of fit nilai $R^{2}$ sebesar 0,861135 menunjukkan bahwa 86,1135 persen dari variasi Penanaman modal asing $(Y)$ dapat dijelaskan oleh variabel Tingkat suku bunga international $\left(X_{1}\right)$, Kurs Rupiah terhadap Dollar $\left(X_{2}\right)$, Tingkat suku bunga domestik $\left(X_{3}\right)$, Inflasi $\left(X_{4}\right)$ Produk domestik bruto $\left(X_{5}\right)$ sedangkan sisanya 13,8865 persen dijelaskan oleh variabel lain di luar model.

4.1.5. Rekapitulasi Hasil Uji Hipotesis

Rekapitulasi hasil pengujian hipotesis regresi linier berganda pada persamaan yang ada adalah sebagai berikut:

$Y_{F D I}=-83,717+0,081 X_{1_{L I B O R}}-1,125 X_{2_{\text {KURS }}}+0.896 X_{3 \text { JIBOR }}-0.21 X_{4_{I N F L A S I}}+16,319 X_{5_{P D B}}$

Tabel 7. Rekapitulasi Hipotesis Penanaman Modal Asing (Y) 


\section{Buana Akuntansi}

Herry dan Dewi

Vol. 6 No. 2

ISSN 2528-1119

E-ISSN 2580-5452

\begin{tabular}{|c|c|c|c|c|c|}
\hline Uji F atau & $\boldsymbol{F}_{\text {Statistic }}$ & $\mathbf{\alpha}$ & $F_{\text {hitung }}$ & $F_{\text {table }}$ & Hipotesis \\
\hline $\begin{array}{l}\text { Pengaruh } \\
\text { Secara } \\
\text { Simultan }\end{array}$ & 0,000000 & 0,05 & 43,16851 & 2,70 & $\begin{array}{l}H_{0} \text { ditolak } \\
H_{1} \text { diterima }\end{array}$ \\
\hline \multicolumn{6}{|c|}{ Terdapat pengaruh yang signifikan } \\
\hline Variable & $\boldsymbol{P}_{\text {Value }}$ & $\mathbf{\alpha}$ & $t_{\text {hitung }}$ & $t_{\text {table }}$ & Hipotesis \\
\hline \multirow{2}{*}{$\begin{array}{l}\text { Tingkat suku } \\
\text { bunga } \\
\text { international } \\
\text { LIBOR }\left(X_{1}\right)\end{array}$} & 0,8251 & 0,05 & 0,223050 & 1,69726 & $\begin{array}{l}H_{0} \text { diterima } \\
H_{1} \text { ditolak }\end{array}$ \\
\hline & \multicolumn{5}{|c|}{$\begin{array}{l}\text { Tidak pengaruh signifikan dan negatif terhadap } \\
\text { Penanaman modal asing langsung }(Y)\end{array}$} \\
\hline \multirow{2}{*}{$\begin{array}{l}\text { Kurs Rupiah } \\
\text { terhadap Dollar } \\
\qquad\left(X_{2}\right)\end{array}$} & 0,0002 & 0,05 & $-4,337005$ & 1,69726 & $\begin{array}{l}H_{0} \text { ditolak } \\
H_{1} \text { ditolak }\end{array}$ \\
\hline & \multicolumn{5}{|c|}{$\begin{array}{l}\text { Pengaruh signifikan dan negatif terhadap Penanaman } \\
\text { modal asing langsung }(Y)\end{array}$} \\
\hline \multirow{2}{*}{$\begin{array}{c}\text { Tingkat suku } \\
\text { bunga domestik } \\
\text { JIBOR }\left(X_{3}\right)\end{array}$} & 0,0008 & 0,05 & 3,749938 & 1,69726 & $\begin{array}{l}H_{0} \text { ditolak } \\
H_{1} \text { diterima }\end{array}$ \\
\hline & \multicolumn{5}{|c|}{$\begin{array}{l}\text { Pengaruh signifikan dan positif terhadap Penanaman } \\
\text { modal asing langsung }(Y)\end{array}$} \\
\hline \multirow[t]{2}{*}{ Inflasi $\left(X_{4}\right)$} & 0,0197 & 0,05 & $-2,468129$ & 1,69726 & $\begin{array}{l}H_{0} \text { ditolak } \\
H_{1} \text { ditolak }\end{array}$ \\
\hline & \multicolumn{5}{|c|}{$\begin{array}{l}\text { Pengaruh signifikan dan negatif terhadap Penanaman } \\
\text { modal asing langsung }(Y)\end{array}$} \\
\hline \multirow{2}{*}{$\begin{array}{c}\text { Produk } \\
\text { domestik bruto } \\
\left(X_{5}\right)\end{array}$} & 0,0000 & 0,05 & 9,603197 & 1,69726 & $\begin{array}{l}H_{0} \text { ditolak } \\
H_{1} \text { ditolak }\end{array}$ \\
\hline & \multicolumn{5}{|c|}{$\begin{array}{l}\text { Pengaruh signifikan dan positif terhadap Penanaman } \\
\text { modal asing langsung }(Y)\end{array}$} \\
\hline
\end{tabular}

a. Secara simultan variabel Tingkat suku bunga international $\left(X_{1}\right)$, Kurs Rupiah terhadap Dollar $\left(X_{2}\right)$, Tingkat suku bunga domestik $\left(X_{3}\right)$, Inflasi $\left(X_{4}\right)$ Produk domestik bruto $\left(X_{5}\right)$ terdapat pengaruh yang signifikan terhadap Penanaman modal asing $(Y)$

b. Secara parsial variable Tingkat suku bunga domestik $\left(X_{3}\right)$ dan Produk domestik bruto $\left(X_{5}\right)$ pengaruh signifikan dan positif terhadap Penanaman modal asing $(Y)$. Sedangkan variabel Kurs Rupiah terhadap Dollar $\left(X_{2}\right)$ dan Inflasi $\left(X_{4}\right)$ pengaruh signifikan dan negatif terhadap Penanaman modal asing $(Y)$. Hanya variabel Tingkat suku bunga international $\left(X_{1}\right)$ tidak pengaruh signifikan dan negatif terhadap Penanaman modal asing $(Y)$.

c. Nilai $R^{2}$ sebesar 0,861135 menunjukkan bahwa 86,1135 persen dari variasi Penanaman modal asing $(Y)$ dapat dijelaskan oleh variabel Tingkat suku bunga international $\left(X_{1}\right)$, Kurs Rupiah terhadap Dollar $\left(X_{2}\right)$, Tingkat suku bunga domestik $\left(X_{3}\right)$, Inflasi $\left(X_{4}\right)$ Produk domestik bruto $\left(X_{5}\right)$ sedangkan sisanya 13,8865 persen dijelaskan oleh variabel lain di luar model.

4.1.6. Hasil Uji Kelayakan Model

Hasil uji kelayakan model menunjukkan bahwa model penelitian telah memenuhi the goodness of an econometric model hasil uji berikut ini:

1. Theoretical Plausibility 


\section{Buana Akuntansi}

Model penelitian ini memperlihatkan bahwa hasil uji telah sesuai dengan ekspektasinya dari teori ekonomi menjadi dasar pemikirannya.

Tabel 8. Hasil Uji Kesesuaian Teori

\begin{tabular}{|c|c|c|c|}
\hline Hubungan Antar Variable & $\begin{array}{c}\text { Pra } \\
\text { Estimasi }\end{array}$ & $\begin{array}{l}\text { Pasca } \\
\text { Estimasi }\end{array}$ & Kesesuaian \\
\hline $\begin{array}{l}\text { Secara simultan Tingkat suku } \\
\text { bunga international }\left(X_{1}\right) \text {, Kurs } \\
\text { Rupiah terhadap Dollar }\left(X_{2}\right) \text {, } \\
\text { Tingkat suku bunga domestik } \\
\left(X_{3}\right) \text {, Inflasi }\left(X_{4}\right), \text { Produk } \\
\text { Domestik Bruto }\left(X_{5}\right) \text { terhadap } \\
\text { Penanaman modal asing } \\
\text { langsung }(Y)\end{array}$ & $\begin{array}{l}\text { Pengaruh } \\
\text { signifikan }\end{array}$ & $\begin{array}{l}\text { Pengaruh } \\
\text { signifikan }\end{array}$ & Sesuai \\
\hline $\begin{array}{l}\text { Pengaruh Tingkat suku bunga } \\
\text { international }\left(X_{1}\right) \text { terhadap } \\
\text { Penanaman modal asing } \\
\text { langsung }(Y)\end{array}$ & $\begin{array}{c}\text { Tidak } \\
\text { Signifikan } \\
\text { negatif }\end{array}$ & $\begin{array}{c}\text { Tidak } \\
\text { Signifikan } \\
\text { negatif }\end{array}$ & Sesuai \\
\hline $\begin{array}{l}\text { Pengaruh Kurs Rupiah } \\
\text { terhadap Dollar }\left(X_{2}\right) \text { terhadap } \\
\text { Penanaman modal asing } \\
\text { langsung }(Y)\end{array}$ & $\begin{array}{c}\text { Signifikan } \\
\text { negatif }\end{array}$ & $\begin{array}{c}\text { Signifikan } \\
\text { negatif }\end{array}$ & Sesuai \\
\hline $\begin{array}{l}\text { Pengaruh Tingkat suku bunga } \\
\text { domestik }\left(X_{3}\right) \text { terhadap } \\
\text { Penanaman modal asing } \\
\text { langsung }(Y)\end{array}$ & $\begin{array}{c}\text { Signifikan } \\
\text { positif }\end{array}$ & $\begin{array}{c}\text { Signifikan } \\
\text { positif }\end{array}$ & Sesuai \\
\hline $\begin{array}{l}\text { Pengaruh Inflasi }\left(X_{4}\right) \text { terhadap } \\
\text { Penanaman modal asing } \\
\text { langsung }(Y)\end{array}$ & $\begin{array}{c}\text { Signifikan } \\
\text { negatif }\end{array}$ & $\begin{array}{c}\text { Signifikan } \\
\text { negatif }\end{array}$ & Sesuai \\
\hline $\begin{array}{l}\text { Produk Domestik Bruto }\left(X_{\mathrm{5}}\right) \\
\text { terhadap Penanaman modal } \\
\text { asing langsung }(Y)\end{array}$ & $\begin{array}{c}\text { Signifikan } \\
\text { positif }\end{array}$ & $\begin{array}{c}\text { Signifikan } \\
\text { positif }\end{array}$ & Sesuai \\
\hline
\end{tabular}

2. Accuracy of the Estimates of the Parameter

Model penelitian ini menghasilkan estimator koefisien regresi yang akurat atau tidak bias dan signifikan. Asumsi analisis terpenuhi dan probabilitas kesalahan statistik dari model sangat rendah atau $\mathrm{p}$-value $<\mathrm{a}$

a. Secara simultan pengaruh Tingkat suku bunga international $\left(X_{1}\right)$, Kurs Rupiah terhadap Dollar $\left(X_{2}\right)$, Tingkat suku bunga domestik $\left(X_{3}\right)$, Inflasi $\left(X_{4}\right)$ Produk Domestik Bruto $\left(X_{5}\right)$ terhadap Penanaman modal asing $(Y)$. Penelitian menghasilkan estimator koefisien regresi yang akurat atau tidak bias dan signifikan. Asumsi analisis terpenuhi dan probabilitas kesalahan statistik dari model sangat rendah menghasilkan $p$-value untuk semua variabel $=$ $0,0000<\alpha=0,05$

b. Secara partial pengaruh Tingkat suku bunga international $\left(X_{1}\right)$, Kurs Rupiah terhadap Dollar $\left(X_{2}\right)$, Tingkat suku bunga domestik $\left(X_{3}\right)$, Inflasi $\left(X_{4}\right)$ Produk Domestik Bruto $\left(X_{5}\right)$ terhadap Penanaman modal asing $(Y)$. Penelitian menghasilkan estimator koefisien regresi yang akurat atau tidak bias dan signifikan. Asumsi analisis terpenuhi dan probabilitas kesalahan statistik dari model sangat rendah: dimana Tingkat suku bunga international $\left(X_{1}\right)$ p-value $=0,8251>a=0,05$, Kurs Rupiah terhadap Dollar $\left(X_{2}\right)$ p-value $=0,0002<a=0,05$, Tingkat suku bunga domestik $\left(X_{3}\right)$ p-value $=0,0008<\alpha=0,05$, Inflasi $\left(X_{4}\right)$ p-value $=0.0197$ $<\mathrm{a}=0,05$, Produk Domestik Bruto $\left(X_{5}\right)$ p-value $=0,0000<a=0,05$. 


\section{Buana Akuntansi}

\section{Explanatory Ability}

Model penelitian memiliki kemampuan yang tinggi dalam menjelaskan hubungan antar fenomena ekonomi yang dikaji. Standard error of estimates (SE), dimana variance error of estimates $=S E^{2}<$ mean square of regression dalam tabel Anova. Demikian pula seluruh Standard error dari koefisien regresi yang signifikan bernilai lebih kecil daripada $1 / 2$ kali nilai koefisien regresinya sebagaimana dapat dilihat pada tabel sebelumnya dan tabel di bawah ini:

Tabel 9. Hasil Uji Kemampuan Menjelaskan

\begin{tabular}{|c|c|c|c|c|}
\hline Explanatory Ability & $\begin{array}{c}\text { Standard } \\
\text { Error }\end{array}$ & Coefficient & $\begin{array}{c}1 / 2 \\
\text { Coefficient }\end{array}$ & Hasil Uji \\
\hline $\begin{array}{l}\text { Secara simultan Tingkat } \\
\text { suku bunga international } \\
\left(X_{1}\right) \text {, Kurs Rupiah terhadap } \\
\text { Dollar }\left(X_{2}\right) \text {, Tingkat suku } \\
\text { bunga domestik }\left(X_{3}\right) \text {, Inflasi } \\
\left(X_{4}\right) \text {, Produk Domestik } \\
\text { Bruto }\left(X_{5}\right) \text { terhadap } \\
\text { Penanaman modal asing(Y) }\end{array}$ & 2,967650 & 255,4014 & 127,7007 & $\begin{array}{c}\mathrm{SE}<1 / 2 \\
\text { Coeffient }\end{array}$ \\
\hline $\begin{array}{l}\text { Pengaruh Tingkat suku } \\
\text { bunga international }\left(X_{1}\right) \\
\text { terhadap Penanaman } \\
\text { modal asing }(Y)\end{array}$ & 0,363531 & 0,081086 & 0,040543 & $\begin{array}{c}\mathrm{SE}>1 / 2 \\
\text { Coeffient }\end{array}$ \\
\hline $\begin{array}{l}\text { Pengaruh Kurs Rupiah } \\
\text { terhadap Dollar }\left(X_{2}\right) \\
\text { terhadap Penanaman } \\
\text { modal asing }(Y)\end{array}$ & 0,259310 & $-1,124630$ & $-0,562315$ & $\begin{array}{c}\text { SE }>1 / 2 \\
\text { Coeffient }\end{array}$ \\
\hline $\begin{array}{l}\text { Pengaruh Tingkat suku } \\
\text { bunga domestik }\left(X_{3}\right) \\
\text { terhadap Penanaman } \\
\text { modal asing }(Y)\end{array}$ & 0,238881 & 0,895787 & 0,4478935 & $\begin{array}{c}\mathrm{SE}<1 / 2 \\
\text { Coeffient }\end{array}$ \\
\hline $\begin{array}{l}\text { Pengaruh Inflasi }\left(X_{4}\right) \\
\text { terhadap Penanaman } \\
\text { modal asing }(Y)\end{array}$ & 0,085101 & $-0,210041$ & $-0,1050205$ & $\begin{array}{c}\mathrm{SE}>1 / 2 \\
\text { Coeffient }\end{array}$ \\
\hline $\begin{array}{l}\text { Pengaruh Produk Domestik } \\
\text { Bruto }\left(X_{5}\right) \text { terhadap } \\
\text { Penanaman modal asing }(Y)\end{array}$ & 1,699403 & 16,31970 & 8,15985 & $\begin{array}{c}\mathrm{SE}<1 / 2 \\
\text { Coeffient }\end{array}$ \\
\hline
\end{tabular}

\subsection{Pembahasan}

4.2.1. Variabel Tingkat suku bunga international $\left(X_{1}\right)$ tidak pengaruh signifikan dan negatif terhadap Penanaman modal asing $(\mathrm{Y})$

Hasil penelitian ini sesuai dengan teori klasik dan keynes, yang menjelaskan bahwa pengaruh dari suku bunga terhadap investasi berbanding terbalik, pengaruh suku bunga luar negeri terhadap tingkat penanaman modal asing juga dipengaruhi oleh keadaan ekonomi internasional yang tercermin dari suku bunga libor, disamping itu juga para investor juga memperhatikan keadaan ekonomi negara yang dituju untuk melakukan investasinya.

4.2.2. Variabel Kurs Rupiah terhadap Dollar $\left(X_{2}\right)$ tidak pengaruh signifikan dan negatif terhadap Penanaman modal asing $(Y)$

Nilai kurs berkaitan dengan konsep daya saing (competitivenes). Hal ini akan mendorong mengalirnya penanaman modal asing ke negara yang mengalami depresiasi nilai tukar. Harus digaris bawahi bahwa tidak kemudian mengambil kebijakan untuk menurunkan nilai tukar demi menarik investasi kedalam sebuah negara, akan tetapi ketika nilai tukar terdepresiasi akan menjadi salah satu bahan pertimbangan bagi investor-investor, khususnya investorinvestor asing untuk melakukan investasinya ke negara tersebut.

4.2.3. Variabel Tingkat suku bunga domestik $\left(X_{2}\right)$ pengaruh signifikan dan negatif terhadap Penanaman modal asing $(Y)$ 


\section{Buana Akuntansi}

Terdapatnya pengaruh yang signifikan dan negatif antara tingkat suku bunga domestik terhadap penanaman modal asing mengindikasikan bahwa penanaman modal asing di Indonesia ditentukan oleh tingkat suku bunga domestik. Terjadinya peningkatan tingkat suku bunga domestik maka penanaman modal asing akan mengalami penurunan. Begitu sebaliknya, apabila tingkat suku bunga domestik mengalami penurunan maka penanaman modal asing akan mengalami peningkatan karena biaya dari investasi mengalami penurunan.

4.2.4. Variabel Inflasi $\left(X_{4}\right)$ pengaruh signifikan dan positif terhadap Penanaman modal asing $(Y)$

Tingkat inflasi berpengaruh signifikan positif terhadap penanaman modal asing menyatakan bahwa kondisi inflasi di Indonesia bukan merupakan hal yang menjadi penghalang investor asing dalam melakukan investasinya di Indonesia akan tetapi dimungkinkan tingkat inflasi Indonesia masih relatif rendah dan stabil rata-rata inflasi.

4.2.5. Variabel Produk domestic bruto $\left(X_{5}\right)$ pengaruh signifikan dan negatif terhadap Penanaman modal asing $(Y)$

Berdasarkan hasil uji t menunjukkan koefisien variabel Produk domestic bruto di Indonesia sebesar 16,319. Hal ini menunjukkan bahwa penanaman modal asing akan meningkatkan sebesar 16,319 satuan untuk tiap tambahan 1 satuan. Hasil koefisien ini juga menunjukkan bahwa Produk Domestik Bruto berpengaruh positif signifikan terhadap penanaman modal asing. Teori elektik produksi dari Dunning menyatakan bahwa jika sebuah perusahaan bermaksud melakukan investasi di luar negeri maka tergantung pada tiga jenis keunggulan penting yang salah satunya adalah berdasarkan lokasi. Pemilihan lokasi berdasarkan negara yang lebih mempunyai daya beli yang cukup untuk produk yang dihasilkan oleh perusahaan tersebut. Apabila Indonesia menunjukkan pertumbuhan ekonomi yang positif maka akan semakin mengundang daya tarik investor untuk berinvestasi, kemudian juga akan meningkatkan jumlah penanaman modal asing masuk ke Indonesia.

\section{Kesimpulan, Keterbatasan, dan Saran}

Berdasarkan hasil pengolahan data dan pembahasan sebelumnya maka dapat disimpulkan bahwa secara umum penanaman modal asing memiliki efek positif, tetapi seharusnya Indonesia tidak hanya fokus pada arus masuk penanaman modal asing, tetapi juga menyelidiki kebijakan yang akan memaksimalkan manfaat dari arus masuk penanaman modal asing melalui komposisi yang tepat.

Berdasarkan hasil kesimpulan maka dapat disarankan: Untuk mengurangi ketergantungan terhadap penanaman modal asing, dengan cara meningkatkan modal dalam negeri dengan melakukan mobilisasi dana masyarakat. Hal ini dapat memperkokoh perekonomian Indonesia dan mengurangi ketergantungan dari arus modal asing dan pinjaman luar negeri yang telah menjadi salah satu penyebab terpuruknya perekonomian Indonesia.

\section{Daftar Pustaka}

Anton, H. Gunawan. Anggaran Pemerintah dan Inflasi di Indonesia Gramedia Pustaka Utama: Jakarta.1991 


\section{Buana Akuntansi}

Herry dan Dewi

Vol. 6 No. 2

ISSN 2528-1119

E-ISSN 2580-5452

Abdul Khaliq, Foreign Direct Investment and Economic Growth: Empirical Evidence from Indonesia. 2007

Adiningsih, Sri. Perangkat Analisis dan Teknik Analisis Investasi di Pasar Modal Indonesia. Jakarta: P.T. Bursa Efek Jakarta. 1998

Adler Haymens Manurung Memahami Seluk Beluk Investasi, PT. Adler Manurung, Jakarta. 2003

Afrizal, M. "Analisis Aset Tetap (Fixed Asset) Pemeritah Kabupaten Bengkalis Tahun 2009", UGM, Yogyakarta 2010

Alan M.Rugman, Bisnis Internasional, PT Pustaka Binaan Pressindo, 1993

Arsyad, Lincolin, Ekonomi Pembangunan. Bagian Penerbitan Sekolah Tinggi Ilmu Ekonomi YKPN, Yogyakarta. 2004

Assaf Razin \& Efraim Sadka, Foreign Direct Investment: Analysis of Aggregate Flows 2007

Aviral Kumar Tiwari and Mihai Mutascu, Economic Analysis \& Policy, Vol. 41 No. 2, september 2011. Economic Growth and FDI in Asia: A Panel-Data Approach.

Barrell, R., and Pain, N., "Foreign Direct Investment, Technological Change, and Economic Growth within Europe," The Economic Journal 107(445), 1770-1786. (1997)

Barro, R., and Sala-i-Martin, X., Economic Growth. MIT Press, Cambridge, MA. 1995

Basir Barthos, Manajemen Sumber Daya Manusia Suatu Pendekatan Makro, PT Bumi Aksara, Jakarta, 2004

Basu Swastha, Pengantar Bisnis Modern, Pengantar Ekonomi Perusahaan Modern, Jakarta : Liberty 2000

Bende-Nabende, A, and Ford, J.L, "FDI, Policy Adjustment and Endogenous Growth: Multiplier Effect from a Small Dynamic Model for Taiwan, 1959-1998," World Development 26(7), 13151330. (2003)

Boediono. "Pengantar Ilmu Ekonomi Makro Seri Sinopsis" Fakultas Ekonomi \& Bisnis UGM. Yogyakarta, 2012.

Borensztein, E., de Gregorio, J., and J-W Lee, "How does foreign direct investment affect economic growth?" Journal of international Economics 45, 115-135. (1998)

Brinda Sooreea-Bheemul and Rajeev Sooreea. Missing causality links between foreign direct investment, exports, domestic investment and economic growth. International Journal of Business and Emerging Markets (IJBEM),Vol.5,No.4.2013

Bungin, Burhan. Penelitian Kualitatif. Jakarta: Kencana Predana Media Group. 2011

Cahyanto, Arief Bagus. Analisis Variabel Ekonomi Makro Terhadap Penanaman Modal Asing di Indonesia. Universitas Brawijaya Malang 2012

Case,Karl.E. \& Fair,Ray.C. Principles of Economics. Eighth Edition. New Jersey: Prentice Hall, 2007.

Mphil Nachrowi dan Hardius Usman, Pendekatan Populer dan Praktis Ekonometrika untuk Analisis Ekonomi dan Keuangan, 2006

David K. Eiteman, Arthur I. Stonehill and Michael H. Moffett, Multinational Business Finance Paperback - International Edition, 2004

Dirk Willem te Velde, Policies Towards Foreign Direct Investment in Developing Countries: Emerging Best-Practices and Outstanding Issues, Overseas Development Institute, London 2001

Don Bellante \& Mark Janson. Ekonomi Ketenagakerjaan. Lembaga Penerbit Fakultas Ekonomi Universitas Indonesia, Jakarta. 2006 


\section{Buana Akuntansi}

Herry dan Dewi

Vol. 6 No. 2

ISSN 2528-1119

E-ISSN 2580-5452

Eatzaz Ahmad and Anis Hamdani. The Role of Foreign Direct Investment In Economic Growth. Pakistan Economic and Social Review Volume XLI, No. 1\&2 (2003), pp. 29-43

Elhanan Helpman, The Mystery of Economic Growth. Harvard University Press, MA (2004)

Eliza, Messayu. Analisis Pengaruh Makroekonomi Terhadap Investasi Asing di Indonesia. Jurnal. Malang : Universitas Brawijaya, 2013.

Eiteman, David K, Arthur L. Stonehill, dan Michael H. Moffet. 1989, “Multinational Bussiness Finance". Ninth edition, Addition-Wesley Publishing Company, Inc. United State of America 1989

Fabozzi, Frank J and Franco Modigliani, 1996. Capital Markets, Second Edition, 1996

Feldstein, Martin 2000, "Aspect of Global Integration: Outlook of The Future", NBER Working Paper, Cambridge, No 7899

Frederic S. Mishkin, The Economics of Money, Banking, and Financial Markets Pearson International Edition, 8th edition. 2007

Frederica dan Juwita. Jurnal. STIE MDP Periode 2007-2012 Pengaruh UMP, Ekspor, dan Kurs Dollar Terhadap Investasi Asing di Indonesia. 2012

Grossman, G., and Helpman, E, Innovation and Growth in the Global Economy. MIT Press, MA. 1991

Gujarati, Damodar. Basic Econometrics, statistical table, McGraw Hill-Inc 2007

Guluzar Kurt Gumus. European Scientific Journal December 2013 edition vol.9, No.34 ISSN: 1857 7881 (Print) e - ISSN 1857- 7431 The Relationship Between Foreign Portfolio Invesment and Macroeconomic Variables

Hooi Hooi Lean. The Impact of Foreign Direct Investment on the Growth of the Manufacturing Sector in Malaysia. International Applied Economics and Management Letters 1(1): $41-45$ (2008).

Hwee Kwan Chow. Managing Capital Flows: The Case of Singapore. ADB Institute Discussion 2008

Ismail Sunny dan Rudiono Rochmat, Tinjauan dan Pembahasan UUPMA dan Kredit Luar Negeri, Jakarta: Pradnya Paramita, 1967

Jhingan. Ekonomi Pembangunan dan Perencanaan, Jakarta : Rajawali Press, 2000

Jose Rizal Joesoef. Pasar Uang dan Valuta Asing, Salemba Empat, Jakarta. 2007

Kamal A. El-Wassal Journal of Economic and Social Research Vol 14(2) 2012, 1-26 University of Alexandria The Impact of Trade Liberalization on Trade Balance in Arab Countries.

Krugman, Paul, "Firesale FDI", Working Paper, Massachusets Institute Of Technology. 1998

Krugman, Paul dan Obstfeld, Maurice. Ekonomi Internasional Teori dan Kebijakan Harper Collins Publisher. Ahli Bahasa. DR. Faisal H. Basri, SE MSc, Jakarta: PT Indeks Kelompok Gramedia. 2004

Laura Alfaro, Foreign Direct Investment and Growth: Does the Sector Matter? 2003

Leonid Melnyk (Ukraine), Oleksandr Kubatko (Ukraine), Serhiy Pysarenko (Canada) Problems and Perspectives in Management, Volume 12, Issue 1, 2014 The impact of foreign direct investment on economic growth: case of post communism transition economies.

Madura, Jeff. International Financial Management, South-Western College Publishing. USA. 2000.

Mankiw, N. Gregory. Teori Makroekonomi Edisi Keempat. Terjemahan : Imam Nurmawan. Jakarta : Erlangga. 2000

Mankiw, G., Romer, D., and N. Weil, 1992, "A Contribution to the Empirics of Economic Growth," Quarterly Journal of Economics 107, 407-437 (1992) 


\section{Buana Akuntansi}

Herry dan Dewi

Vol. 6 No. 2

ISSN 2528-1119

E-ISSN 2580-5452

Manurung, Mandala dan Prathama Rahardja. Uang, Perbankan, dan Ekonomi Moneter, Jakarta: Penerbit Fakultas Ekonomi Universitas Indonesia. 2004

Maurice D Levi, International Finance 5th Edition. 2004

Mehmet Mucuk and M. Tahir Demirsel Selçuk University, Konya, Turkey. Journal of Business, Economics \& Finance ISSN: 2146-7943 The Effect Of Foreign Direct Investments On Unemployment Evidence From Panel Data For Seven Developing Countries.

Mencinger, J. (2003): Does Foreign Direct Investments Always Enhance Economic Growth? Kyklos, Vol 56, 2003

Michael P. Todaro dan Stephen C. Smith.“Pembangunan Ekonomi di Dunia Ketiga”. Edisi Ke delapan. 2004.

Mudrajad Kuncoro, 2001, Metode Kuantitatif (Teori dan Aplikasi untuk Bisnis dan Ekonomi), Unit Penerbit dan Percetakan AMP YKPN, Yogyakarta

Mukhtar. "Metode Praktis Penelitian deskriptif kualitatif “ Referensi (GP Press Group). Jakarta, 2013.

Mulia Nasution, Teori ekonomi Makro "Pendekatan Pada Perekonomian Indonesia", Djambatan, Jakarta. 1997

Mohammad Amin Almfrajia and Mahmoud Khalid Almsafirc. 1877-0428 ( 2014 The Authors. Published by Elsevier Ltd. Open access under CC BY-NC-ND license.Selection and peer-review under responsibility of Universiti Malaysia Kelantan doi: 10.1016/j.sbspro.2014.03.668 Foreign Direct Investment and Economic Growth Literature Review from 1994 to 2012

Najia Saqib, Maryam Masnoon and Nabeel Rafique. Impact of foreign direct investment on economic growth of Pakistan. Advances in Management \& Applied Economics, vol.3, no.1, 2013, 35-45 ISSN: 1792-7544 (print version), 1792-7552 (online)

Nikolas Hourvouliades and Ljupco Davcev. ISSN 2233-1034 - ISBN 978-99938-46-54-3 Researching Economic Development and Entrepreneurship in Transition Economies. 2014

Nopirin, 1994. Pengantar Ilmu Ekonomi Makro dan Mikro. BPFE. Yogyakarta.

Oleksandr Lozovyi and Alina Kudina, Determinants of portfolio flows into CIS countries 2007

Ozturk, Ilhan International Journal of Applied Econometrics and Quantitative Studies Vol. 4-2 (2007) Foreign Direct Investment- Growth Nexus: a Review of The Recent Literature

Paul M. Romer. The Origins of Endogenous Growth Journal of Economic Perspectives - Volume 8, Number 1-(Winter 1994)-Pages 3-22

Polpat Kotrajaras. Faculty of Economics, Chulalongkorn University Applied Economics Journal 17 (2): 12-26 Foreign Direct Investment and Economic Growth: A Comparative Study among East Asian Countries.

Reza Ahmadi and Mojtaba Ghanbarzadeh Journal of Scientific Research 10 (2):174-182, 2011 ISSN 1990-9233 FDI, Exports and Economic Growth: Evidence from Mena Region.

Riduwan dan Engkos Ahmad Kuncoro. Cara Menggunakan dan Memakai Analisis Jalur (Path Analysis). Bandung : Alfabeta 2007

Rohmana,Yana. Jurnal Keuangan Analisis Faktor-Faktor yang Mempengaruhi Investasi Asing di Indonesia. 2009.

Romer, P.M., “Endogenous Technological Change," Journal of Political Economy 98, S71-S102 (1990) 


\section{Buana Akuntansi}

Herry dan Dewi

Vol. 6 No. 2

ISSN 2528-1119

E-ISSN 2580-5452

Rupal Chowdhary and Vivek Kushwaha. Journal of Transformative Entrepreneurship ISSN: 22893075 (Print) 2289-4462 Vol. 1, Issue 2, pp: 74-82 (2013). Domestic Investment, Foreign Direct Investment and Economic Growth in India since Economic Reforms.

Sachs, J.D., and Warner, A.M., "The Curse of Natural Resources," European Economic Review 45, 827-38. (2001)

Sadono Sukirno. “Makro Ekonomi Teori Pengantar" PT. Raja Grafindo Persada. Jakarta, 2012.

Sala-i-Martin, X., and Subramian, A., "Addressing the Natural Resources Curse: An Illustration from Nigeria," NBER Working Paper 9808.(2003)

Samuelson, Paul A. dan William D. Nordhaus Macroeconomics. Seventeenth Edition. McGraw-Hill Higher Education. 2004

Sangkyun,Park Journal Financial Analyst "Rationality of negative Stock Price Responses to Strong Economics Activity" 1997

Sarwedi. Jurnal Akuntansi \& Keuangan Vol. 4 No. 1 "Investasi di Indonesia dan Faktor Yang Mempengaruhinya". 2002

Simanjuntak, Payaman J. Pengantar Ekonomi Sumber Daya Manusia, Jakarta: Fakultas Ekonomi UI. 2001

Sitinjak, Elyzabeth Lucky Maretha dan Widuri Kurniasari. Jurnal Riset Ekonomi dan Manajemen, vol.3 no.3 2003. Indikator-Indikator Pasar Saham Dan Pasar Uang yang Saling Berkaitan Ditinjau Dari Pasar Saham Sedang Bullish dan Bearish.

Solow, Robert M., "Technological Change and the Aggregate Production Function," Review of Economics and Statistics 39 (August), 312-320 (1957)

Statistik Indonesia, 70 Tahun Jakarta Pusat : Badan Pusat Statistik 2015

Sudarsono "Pengantar Ekonomi Mikro" PT.Pustaka LP3ES Jakarta 1995

Suliyanto. Ekonometrika Terapan: Teori dan Aplikasi dengan SPSS. Yogyakarta. 2011

Sumantoro, Kerjasama Patungan \& Modal Asing, penerbit alumni Bandung, 1984

Sumantoro, Kegiatan Perusahaan Multinasionar. Gramedia, Jakarta. 1987

Sunariyah. Pengantar Pengetahuan Pasar Modal, Edisi Kelima, UPP STIM YKPN, Yogyakarta. 2006

Soumia Zenasni and Abderrezzak Benhabib, "The Determinants of Foreign Direct Investment and Their Impact on Growth: Panel Data Analysis for AMU Countries," International Journal of Innovation and Applied Studies, vol. 2, no. 3, pp. 300-313, March 2013

Tam Bang Vu, Byron Gangnes, Ilan Noy. Is Foreign Direct Investment Good for Growth? Evidence from Sectoral Analysis of China and Vietnam. 2007

Todaro M.P. Pembangunan Ekonomi di Dunia Ketiga, Penerbit Erlangga. Jakarta 2006

Vu, T.B., Gangnes, B., and Noy, I., "Is Foreign Direct Investment Good for Growth? Answer Using Sectoral Data from China and Vietnam," 2006

Wing Wahyu Winarno. "Analisis Ekonometrika dan Statistik dengan E-Views".Edisi Ketiga 2011

Yılmaz Bayar. Savings, Foreign Direct Invesment Inflows and Economic Growth in Emerging Asian Economies. Asian Economic and Financial Review, 2014, 4(8): 1106-1122

Yuyun Wirasasmita. 2007. Uji Kelayakan Model; Extended Handout Metode Penelitian Enonomi dan Bisnis, Bandung: UNPAD. 
Herry dan Dewi

\section{Buana Akuntansi}

Vol. 6 No. 2

ISSN 2528-1119

E-ISSN 2580-5452

Zenasni Soumia and Benhabib Abderrezzak International Journal of Innovation and Applied Studies ISSN 2028-9324 Vol. 2 No. 3 Mar. 2013, pp. 300-313. The Determinants of Foreign Direct Investment and Their Impact on Growth: Panel Data Analysis for AMU Countries. 